\title{
Yesus Sebagai Anak Allah Menurut Injil Matius dan Implementasinya Dalam Berapologetika
}

\author{
Hery Susanto \\ Sekolah Tinggi Teologi Jemaat Kristus Indonesia \\ kristocarly@gmail.com
}

Diterima : 4 Nov. 2019

Direvisi : 26 Nov. 2019

Disetujui : 2 Des. 2019

\begin{abstract}
Abstrak
Injil Matius memiliki ciri khusus yang menekankan kesinambungan antara nubuat dalam Perjanjian Lama dan penggenapan di dalam Perjanjian Baru. Secara khusus Yesus ditonjolkan dari sisi keberadaan identitas-Nya yang beranekaragam menunjukkan bahwa di dalam diri Yesus terdapat divine sonship (keputra ilahian) yang tak terbantahkan. Atas dasar inilah orang Kristen semestinya berapologet sebagaimana orang-orang di dalam kisah Yesus tersebut mengakui kebenaran itu bukan sebagai sebuah doctrinal tetapi sebuah confession yang diyakini dalam iman yang sungguh kepada Tuhan Yesus.
\end{abstract}

Kata kunci: Anak Allah, divine sonship, apologetika

\begin{abstract}
The Gospel of Matthew has a special feature that emphasizes the continuity between prophecy in the Old Testament and fulfillment in the New Testament. In particular Jesus highlighted in terms of the existence of His diverse identity shows that in Jesus there is an undisputed divine sonship (divine sonship). It is on this basis that Christians should be practicing psychology as the people in the story of Jesus acknowledge that truth not as a doctrinal but a confession believed in true faith in the Lord Jesus.
\end{abstract}

Keywords: Son of God, divine sonship, apologetics 
LOGIA : Jurnal Teologi Pentakosta

Vol. 1, No. 1 (Desember 2019)

ISSN : 2716-4322 (Cetak) 2716-2834 (Online)
Available Online at

http://sttberea.ac.id/e-journal/index.php/logia

DOI : $10.37731 / \log . v 1$ i1.21

\section{PENDAHULUAN}

Yesus sebagai Anak Allah merupakan sebuah konsep di dalam Injil Alkitab, yang menunjukkan sisi kemanusiaan Yesus sekaligus sisi ke-ilahian Allah. Konsep ini bukan berarti 'menduakan Allah" atau menganggap Allah memiliki anak secara harafiah. Pemaknaannya memerlukan telaah teologis agar orang lain dapat memahaminya dengan benar.

Injil Matius memulai kisahnya dengan menunjukkan narasi kelahiran Yesus sebagai bayi di dunia. Matius mengisahkan tentang silsilah (biblos geneseos) Yesus Kristus sebagai anak Daud, anak Abraham. (1:1). Identitas ini merupakan hal yang penting untuk dimengerti karena kedua nama besar tersebut merupakan tokoh penting dalam tradisi Yahudi.

Fakta bahwa Yesus itu adalah manusia seutuhnya yang menjadi penyelamat dunia, menjadikan-Nya memiliki banyak oposisi dan ketidaksepakatan dalam banyak hal yang terkadang orang Kristen sendiri tidak dapat menjelaskan konsep ini dengan baik. Oleh sebab itu dalam artikel ini akan dibahas tentang identitas Yesus yang dinyatakan berdasarkan Injil Matius dan bagaimana konsep ini digunakan sebagai dasar berapologet terhadap tuduhan bahwa "Allah tidak beranak atau memperanakkan".

\section{IDENTITAS YESUS DALAM KONTEKS MATIUS}

\section{Kelahiran}

Injil Matius dengan sangat jeli menguraikan silsilah Yesus sebagai bukti bahwa Yesus bukanlah sekedar anak tukang kayu, tetapi merupakan keturunan orang penting di dalam sejarah orang Israel. Hal ini penting untuk menunjukkan adanya otoritas dan wibawa khusus yang disandangkan kepada-Nya. Berbagai pihak menyebut Yesus dengan sebutan yang berbeda untuk memberikan sebuah gambaran relasional antara Yesus dengan bangsa Israel secara pribadi.

\section{Anak Daud, Anak Abraham (1:1, 9:27; 21: 9)}

Ada beberapa ayat yang disebutkan mengenai identitas Yesus sebagai Anak Daud, yang menunjuk kepada lambang kekuasaan atas Israel, dan otoritas raja ada di dalam diri Yesus. Anak Abraham menunjukkan penggenapan bahwa melalui keturunan Abrahamlah generasi berikutnya di seluruh dunia akan diberkati. Betapa pentingnya status posisi Yesus menurut Injil Matius, bagi orang Yahudi pada waktu itu bahwa Yesus akan terlahir sebagai 
LOGIA : Jurnal Teologi Pentakosta

Vol. 1, No. 1 (Desember 2019)

ISSN : 2716-4322 (Cetak) 2716-2834 (Online)
Available Online at

http://sttberea.ac.id/e-journal/index.php/logia

DOI : $10.37731 / \log . v 1 \mathrm{i} 1.21$

penerus generasi raja yang akan membebaskan atau memulihkan kehidupan bangsa Israel.

Sekalipun demikian konsep bangsa Israel pada waktu itu lebih mengarah kepada keturunan atau dinasti raja yang akan memperbaiki masalah sosio politik. Yesus menjadi tokoh utama dalam Injil Matius dan keakuratan data tentang siapa jati diri-Nya dijabarkan dengan detail yang indah,

Dalam Injil Matius, silsilah ini bertujuan untuk membuktikan bahwa Yesus Tuhan adalah anak Daud, dan anak Abraham, dan karena itu dari bangsa dan keluarga yang darinya Sang Mesias akan muncul. Di masa bangsa Israel, Abraham dan Daud merupakan wali utama atas janji yang berkaitan dengan Sang Mesias. Janji tentang berkat diberikan kepada Abraham dan keturunannya, tentang kekuasaan diberikan kepada Daud dan keturunannya. Karena itu, mereka yang memiliki hak dalam Kristus, anak Abraham, yang oleh-Nya semua kaum di muka bumi akan mendapatkan, harus setia dan tunduk kepada Dia sebagai Anak Daud, yang oleh-Nya seluruh kaum di muka bumi akan diperintah. Allah Telah berjanji kepada Abraham bahwa Kristus akan lahir dari keturunannya (Kej. 12:3; 22:18), dan juga kepada Daud bahwa Dia akan lahir dari keturunannya (2 Sam.7:12; Mzm. 89:4.; 132:11). Oleh sebab itu, kalau kita tidak dapat membuktikan bahwa Yesus adalah anak Daud, dan anak Abraham, kita tidak dapat mengakui-Nya sebagai Sang Mesias.

Dalam Injil Matius, hal itu dibuktikan melalui catatan-catatan autentik dari lembagalembaga pencatatan silsilah. Orang Yahudi sangat saksama dalam melestarikan garis silsilah mereka, dan ada providensi di dalamnya, demi menjernihkan garis keturunan Sang Mesias dari bapak-bapak leluhur; lagi pula, sejak kedatangan-Nya, bangsa itu begitu tercerai-berai dan tercampur-baur hingga menimbulkan pertanyaan apakah ada orang di dunia ini yang dapat dengan sah membuktikan bahwa dirinya adalah keturunan Abraham. Namun, ada satu hal yang pasti, tidak seorang pun dapat membuktikan dirinya sebagai anak Harun atau anak Daud, karena itu jabatan imamat dan rajawi harus disudahi, ibarat hilang selamanya, atau diletakkan ke dalam tangan Yesus Tuhan kita. Kristus dalam Injil ini mula-mula disebut Anak Daud, sebab dengan julukan itulah la umumnya diperbincangkan, dan diharapkan, di antara orang Yahudi. Mereka yang mengakui-Nya sebagai Kristus menyebut-Nya Anak Daud (15:22; 20:31; 21:15). Jadi, karena itulah, penulis Injil Matius berusaha menjelaskan bahwa la bukan hanya seorang keturunan Daud, melainkan Sang Anak Daud itu sendiri dan lambang pemerintahan ada di atas bahu-Nya; la bukan sekadar seorang keturunan Abraham, tetapi 
LOGIA : Jurnal Teologi Pentakosta

Vol. 1, No. 1 (Desember 2019)

ISSN : 2716-4322 (Cetak) 2716-2834 (Online)
Available Online at

http://sttberea.ac.id/e-journal/index.php/logia

DOI : $10.37731 / \log . v 1 i 1.21$

Sang Anak Abraham yang dimaksudkan untuk menjadi bapa banyak bangsa. Dengan menyebut Kristus sebagai anak Daud, dan anak Abraham, penulis Injil Matius menunjukkan bahwa Allah setia kepada janji-Nya, dan akan menepati setiap perkataan yang telah diucapkan-Nya. ${ }^{1}$

\section{Imanuel; Allah beserta kita (1:23)}

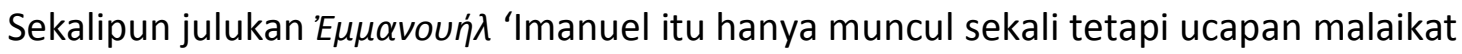
Gabriel kepada Yusuf pada waktu itu memberikan paradigma baru tentang Yesus. Kehadiran Allah yang beserta manusia terwujud melalui lahirnya Yesus ke dunia. Allah yang bertahta di surga mendatangi manusia dan menjadi sama dengan manusia, dalam dimensi 'kefanaan'. Kata ini hanya muncul 3 kali dalam Alkitab, 2 kali di kitab Yesaya dan 1 kali di Injil Matius. Hal ini nampak dari ucapan malaikat tersebut yang berusaha meyakinkan bahwa Allah telah datang dalam bentuk bayi kecil tak berdaya, tetapi justru karena itu, manusia harus membawa kesaksian bahwa Allah yang sedemikian berkuasa rela masuk ke dalam dunia untuk melakukan karya penyelamatan umat-Nya. Allah yang ilahi masuk ke dalam dunia sebagai manusia sehingga keberadaan-Nya atau eksistensinya adalah riil Allah beserta dengan manusia, merasakan apa yang dirasakan manusia secara alami dan sungguh-sungguh memberikan teladan hidup yang jauh lebih dari apa yang manusia hadapi.

Berdasarkan penjelasan dari Baker's Evangelical Dictionary, dikatakan bahwa pada waktu malaikat menampakkan diri pada Yusuf dalam mimpinya, dia mengerti bahwa tunangannya Maria mengandung anak dari Roh Kudus dan akan melahirkan anak yang disebut Imanuel. (Matius 1:18, 23) yang berarti Allah beserta kita, dan diekspresikan lewat inkarnasi, bahwa Allah yang adalah Roh menjadi daging dan menjadikan diri-Nya tinggal bersama manusia (Yoh. 1:14).

When the angel appeared to Joseph in a dream, he learned that his fianc Mary was"with child through the Holy Spirit" and would give birth to a son named"Immanuel" ( Matthew 1:18 Matthew 1:23). "Immanuel" is a Hebrew word meaning "God with us" and expresses the wonder of the incarnation, that God "became flesh and made his dwelling among us" ( John 1:14).In the Old Testament God's presence with his people Israel was particularly evident in the tabernacle ( Exod

\footnotetext{
${ }^{1}$ http://alkitab.sabda.org/verse_commentary.php?book=Mat\&chapter=1\&verse=1, diunggah pada tanggal 22 Agustus 2019, pukul .3.09 WIB.
} 
25:8 ), but the glory that filled the tabernacle was surpassed by the personal presence of God the Son as he revealed the Father during his ministry on earth. Christ's glory was revealed through the miracles he performed ( John 2:11 ). ${ }^{2}$

\section{Raja orang Yahudi, Mesias (2:2, 4; 16:16; 26:63)}

Istilah raja orang Yahudi yang dikatakan oleh malaikat pada saat kelahiran Yesus merupakan janji sekaligus penggenapan dari nubuatan tentang apa yang akan terjadi dengan Yesus. Istilah MESIAS/ ALMASIH/ KRISTUS (artinya : Raja yang diurapi) dipakai sebagai gelar resmi dari tokoh utama yang dinanti-nantikan oleh orang Yahudi, merupakan Juruselamat yang mereka tunggu. Menurut Tanakh Ibrani (Perjanjian Lama), Mesias yang dijanjikan adalah orang yang dipilih Allah, ditetapkan untuk menggenapi suatu tujuan penyelamatan bagi umat Allah, dan menggenapi hukuman terhadap musuh- musuh-Nya. Kepadanya diberikan kuasa untuk memerintah bangsa-bangsa, dan dalam semua tindakannya, yang sesungguhnya bertindak adalah Allah sendiri.

Namun dalam pemahaman orang Yahudi, Mesias yang dijanjikan itu, mereka berpikir harusnya sosok Mesias itu akan memenuhi kriteria sebagai berikut : ${ }^{3}$

1. Membebaskan bangsa Yahudi dari penjajahan (Romawi).

2. Mengumpulkan kembali bangsa Israel dari segala penjuru bumi.

3. Memimpin pada penyembahan pada Tuhan Allah yang benar.

4. Membawa era perdamaian.

5. Mendirikan kembali negara Israel.

Janji akan datangnya Sang Mesias juga diberikan kepada Raja Daud, bahwa Mesias akan datang sebagai salah satu keturunannya, sebagai Raja abadi, seperti dikatakan Tuhan, "Dialah yang akan mendirikan rumah bagi nama-Ku dan aku akan mengokohkan tahta kerajaannya untuk selama-lamanya" (2 Samuel 7:13). Yesaya mengatakan, "Suatu tunas akan keluar dari tunggul Isai (yaitu ayah Daud), dan taruk yang akan tumbuh dari pangkalnya akan berbuah" (Yesaya 11:1). Ini adalah "sebutan" yang lain lagi untuk Mesias, dan menunjukkan bahwa, bahkan setelah pohon keluarga Isai terputus, masih ada satu

\footnotetext{
${ }^{2}$ https://www.biblestudytools.com/dictionaries/bakers-evangelical-dictionary/immanuel.html, diunggah pada tanggal 22 Agustus 2019, pukul 15.29 WIB

${ }^{3} \mathrm{http}: / /$ www.sarapanpagi.org/86-konsep-mesias-dalam-alkitab-dan-menurut-yahudi-vt3193.html diunggah pada tanggal 22 Agustus 2019, pukul 16.00 WIB
} 
LOGIA : Jurnal Teologi Pentakosta

Vol. 1, No. 1 (Desember 2019)

ISSN : 2716-4322 (Cetak) 2716-2834 (Online)
Available Online at

http://sttberea.ac.id/e-journal/index.php/logia

DOI : $10.37731 / \log . v 1 i 1.21$

cabang (taruk) yang tumbuh dari tunggulnya. Ternyata cabang terakhir yang muncul dari silsilah ini akhirnya terbukti merupakan Mesias terjanji. Nubuat hadirnya Mesias dari keturunan Daud, digenapi secara unik dalam diri Yesus. Ayah angkatnya, Yusuf, tunangan Maria termasuk dalam keturunan Daud melalui Salomo dan karenanya mempunyai hak atas tahta (Matius 1:1-16). IbuNya, Maria, juga keturunan Daud melalui Nathan, seperti dijelaskan dalam silsilah dalam Lukas 3:23-31.

Terlebih lagi Yesus yang menjadi seorang raja bagi orang Yahudi, pada masa itu menjadi sebuah hal penting dan didambakan oleh orang-orang Yahudi yang menghendaki lepas dari kekuasaan Romawi. Pada saat penyaliban, frase raja orng Yahudi merupakan olokolok yang Pilatus katakan kepadda Yesus. Tetapi yang tidak disadari oleh mereka bahwa setiap mata yang memandang salib Yesus justru membacanya dan merenungkannya sebagai sebuah penggenapan nubuatan yang sebelumnya tidak mereka pahami. Konsep kerajaan dan raja yang ada dalam benak mereka pada waktu itu sangat berbeda dengan apa yang dinyatakan oleh Yesus.

\section{Baptisan}

\section{Membaptis dengan Roh Kudus dan api (3:11)}

Kedatangan Yesus membaptis dengan Roh Kudus dan api merupakan konsep baru bagi orang-orang Yahudi pada waktu itu. Yohanes Pembaptis membaptis dengan air tetapi Yesus membabptis dengan Roh Kudus. Arti penting dari istilah tersebut adalah menunjukkan otoritas sempurna dari Yesus yang berasal dari surga, yaitu Allah sendiri yang menciptakan manusia dan menghembuskan Roh-Nya ke dalam diri manusia sehingga manusia memiliki hidup. Demikian juga baptis dalam Roh Kudus dilakukan oleh Yesus merupakan gambaran yang indah tentang istilah "Kita" di dalam Kejadian 1:26. Sebuah keutuhan pribadi Allah yang dikaruniakan kepada manusia menjadikan manusia mampu untuk hidup seperti Yesus. Selanjutnya dalam bagian lain dikatakan olehYohanes tentang sebuah kondisi kelahiran baru (Yoh.3) dan Paulus menyatakan sebagai ciptaan baru (1 Korintus). Jadi ketika Yohanes pembabtis mengatakan bahwa Yesus akan membabtis dengan Roh Kudus berarti berdampak total dalam hidup manusia. Hanya Yesus yang sanggup melakukan itu, karena melalui baptisan itu melambangkan kematian dan kebangkitan dari kehidupan lama manusia menjadi manusia baru yang berkenan di hadapan Allah. 
LOGIA : Jurnal Teologi Pentakosta

Vol. 1, No. 1 (Desember 2019)

ISSN : 2716-4322 (Cetak) 2716-2834 (Online)
Available Online at

http://sttberea.ac.id/e-journal/index.php/logia

DOI : $10.37731 / \log . v 1 \mathrm{i} 1.21$

Matius 3:11-12 mengatakan, "Aku membaptis kamu dengan air sebagai tanda pertobatan, tetapi la yang datang kemudian dari padaku lebih berkuasa dari padaku dan aku tidak layak melepaskan kasut-Nya. la akan membaptiskan kamu dengan Roh Kudus dan dengan api. Alat penampi sudah di tangan-Nya. la akan membersihkan tempat pengirikanNya dan mengumpulkan gandum-Nya ke dalam lumbung, tetapi debu jerami itu akan dibakar-Nya dalam api yang tidak terpadamkan." Menurut konteks kalimat ini, api di sini bukanlah api dalam Kisah Para Rasul 2:3, yang berhubungan dengan Roh Kudus, melainkan lautan api (Why. 20:15), dan dilambangkan pula dengan cawan penderitaan. Jika orang Farisi dan orang Saduki mau sungguh-sungguh bertobat dan percaya kepada Tuhan, Tuhan akan membaptis mereka dalam Roh Kudus supaya mereka bisa mendapatkan kehidupan kekal. Jika tidak, Tuhan akan membaptis mereka dalam lautan api untuk dihukum selamanya. Para rasulpun mengalami penderitaan di akhir hidup pelayananya dan menjadi martir, sebagai tanda bahwa baptisan api tersebut memang harus terjadi atau tergenapi.

\section{Anak yang Kukasihi (3:17; 11:27)}

Peristiwa spektakuler berikutnya adalah terbukanya langit dan suara yang keluar dari langit, yang menyatakan bahwa Yesus adalah Anak yang Kukasihi, kepada-Nyalah Aku berkenan. Sebuah pernyataan yang terdengar di hadapan publik. Matius tidak menjelaskan secara eksplisit bahwa semua orang mendengarkan suara tersebut, namun Yohanes mengakui bahwa Yesus benar-benar adalah Anak yang dikasihi, dan semua itu karena Roh Kudus yang memberikan pemahaman kepadanya sehingga Yohanes mengambil sikap sebagai hamba yang paling rendah dan kecil. "membuka tali kasutnyapun aku tidak layak (3:11)". Sebuah sikap yang begitu mengagungkan Yesus sebagai yang diurapi oleh Allah dan menempatkan diri pada posisi hamba yang taat dan setia pada tugasnya.

Pada pasal 11, Yesus menjelaskan identitas diri-Nya dengan sebuah gambaran relasional antara Bapa dan Anak yang saling mengenal. Relasi itu juga diimpartasikan kepada semua orang yang berkenan kepada Anak. Artinya kepada orang-orang beriman kepada Yesus pun akan dapat atau mampu mengenal Yesus dan Allah Bapa, sebagaimana hubungan antara Anak dan Bapa. Menurut Eko Riyadi, Pr, menyatakan bahwa:

“Pernyataan Allah ini menunjukkan bahwa Allah memandang Yesus dalam kerangka keputrailahian (divine sonship) bahwa peran Yesus sebagai Anak Allah melibatkan 
LOGIA : Jurnal Teologi Pentakosta

Vol. 1, No. 1 (Desember 2019)

ISSN : 2716-4322 (Cetak) 2716-2834 (Online)
Available Online at http://sttberea.ac.id/e-journal/index.php/logia DOI : $10.37731 / \log . v 1 \mathrm{i} 1.21$

ketaatan kepada Bapa. Pernyataan ini berhubungan dengan pernyataan mengenai perkenanan Bapa kepada Anak yang dikasihi-Nya." 4

\section{Pencobaan di gurun}

\section{Anak Allah (4:3; 8:29; 14:33; 16:16)}

Matius mencatat Yesus sebagai 'Anak Allah' paling sering disebut. Namun pada bagian ini, yang menyerukan keberadaan Yesus sebagai Anak Allah adalah si Iblis yang mencobai Yesus. Dia tahu persis siapa Dia dan berusaha menggoyahkan jati diri Yesus dengan tiga hal yang paling diinginkan oleh manusia, makanan, tahta, dan kuasa. Bahkan Iblis menggunakan Firman Tuhan sebagai senjatanya, namun Yesus dengan segala keteguhan hati-Nya. Si Iblis mencobai Yesus yang dating ke dunia sebagai manusia. Satu hal yang tidak diketahuinya adalah ketegaran Yesus yang begitu komitmen dan fokus kepada tujuan kedatangan-Nya ke dunia untuk menyelamatkan manusia. Dia tidak terbujuk oleh rayuan iblis, karena Yesus benar-benar dapat melihat perspektif yang berbeda mengenai segala sesuatu di dunia dari kekekalan. Yesus tahu bahwa la akan menang walaupun sangat berat perlawanannya dan sangat menyakitkan. Iblis tidak tahu bahwa upayanya akan gagal justru ketika dia merasa menang dapat menyalibkan Yesus. Situasi berbalik karena Anak Allah memang harus mati untuk menjadi korban penebusan dosa manusia. Yesus adalah tanda, bukti, datangnya Kerajaan dan kuasa Allah di dunia ini. ${ }^{5}$

Simon Petrus juga mengakui Yesus sebagai Mesias, Anak Allah yang hidup. Sebuah pengakuan yang berbeda dari teman-temannya yang lain. Mereka mengenal Yesus tetapi tidak sungguh-sungguh memiliki keintiman, pengenalan pribadi Yesus. Banyak pengakuan dan spekulasi tentang siapa Yesus, dan Yesus tidak menanggapi praduga mereka. Yesus hanya menanggapi pengakuan Simon dengan sebutan 'berbahagialah Simon bin Yunus'. Hal ini menunjukkan bahwa Yesus juga mengenal Simon dan siapa dia dari sisi silsilahnya. Sebuah pengenalan dan penyebutan yang tidak biasa untuk murid-muridNya. Oleh sebab itu Yesus menyebut Simon berbahagia karena 'Allah Bapa di surga yang menyatakannya kepada Simon'. Persis sama dengan peristiwa baptisan yang membuat Yohanes memahami tentang

\footnotetext{
${ }^{4}$ Eko Priyadi Pr, Yesus Kristus Tuhan Kita (Yogyakarta: Kanisius, 2011).138.

${ }^{5}$ Wismoady Wahono, Di Sini Kutemukan: Petunjuk Mempelajari Dan Mengajarkan Alkitab (Jakarta: BPK Gunung Mulia, 2009).411
} 
LOGIA : Jurnal Teologi Pentakosta

Vol. 1, No. 1 (Desember 2019)

ISSN : 2716-4322 (Cetak) 2716-2834 (Online)
Available Online at http://sttberea.ac.id/e-journal/index.php/logia DOI : $10.37731 / \log . v 1 \mathrm{i} 1.21$

Yesus adalah semata-mata karena Allah sendiri yang menggerakkan hatinya, untuk mengakui dalam hati dan mengucapkan dengan mulutnya.

\section{Tuhan, Allah (4:10)}

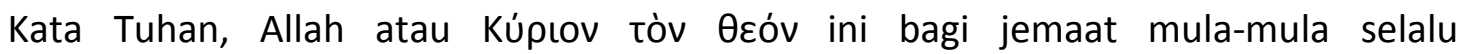
dihubungkan dengan 'parousia' atau kedatangan Kristus (1 Kor.16:22, Why 22:20). Artinya bagi jemaat pada waktu itu, gelar kurios selalu berkaitan dengan otoritas atau kuasa sama dengan Allah. ${ }^{6}$ Banyak penafsir yang mengartikan kurios sebagai tuan bukan Tuhan. Apapun konsepnya, keduanya memiliki substansi yang sama yaitu ketundukan kepada suatu pribadi yang melebihi yang lain. Jadi dimungkinkan bagi orang-orang umum, kata kurios ini dikontraskan dengan doulos atau hamba. Namun bagi orang-orang yang percaya kepada Yesus, Kurios memiliki kuasa yang besar melebihi tuan pada umumnya karena Dia adalah Tuhan.

Yesus tidak meminta kepada iblis untuk menyembah Dia, tetapi berkata bahwa iblispun harus “... menyembah Tuhan, Allahmu, dan hanya kepada Dia sajalah engkau berbakti". Jadi Iblispun sebenarnya adalah makhluk ciptaan yang harus tunduk kepada Tuhan. Allah yang sama dengan Allah yang disembah segala mahluk ciptaan lainnya. Allah yang menjadikan langit dan bumi. Allah dengan segala rancangan dan rencana-Nya harus dilaksanakan tanpa terkecuali. Pernyataan tersebut membuat iblis kemudian pergi meninggalkan Dia, karena tidak dapat lagi melawan. Kuasa dan ketundukan pada otoritas Allah yang tidak dapat dilawan. Oleh sebab itu dikatakan dalam ayat ini bahwa malaikatpun datang melayani Yesus. Kalimat ini menunjukkan secara implisit bahwa Yesuslah Tuhan, dan Yesuslah Allah yang harus disembah. Melalui Dia, segala kuasa Allah dinyatakan. Ada otoritas dan kuasa di dalam perkataan Yesus sebagaimana Allah sendiri yang bersabda.

\section{Pelayanan Yesus}

\section{Yesus sebagai Rabbi (8:19; 12:38)}

Pada umur 30 tahun Yesus mulai mengajar dan Dia mulai menjadi guru atau pengajar yang mengagumkan karena Dia mengajar dengan penuh kuasa. Yesus disebut Rabbi $\delta\llcorner\delta \alpha ́ \sigma \kappa \alpha \lambda \varepsilon$ - dari kata didaskalous yang berarti seorang 'guru besar' di kalangan orang Yahudi. Sebuah status yang tinggi dan terhormat. Nama Yesus semakin populer di kalangan

\footnotetext{
${ }^{6}$ Ch. Abineno, Pokok-Pokok Penting Dari Iman Kristen (Jakarta: BPK Gunung Mulia, 2008).111.
} 
LOGIA : Jurnal Teologi Pentakosta

Vol. 1, No. 1 (Desember 2019)

ISSN : 2716-4322 (Cetak) 2716-2834 (Online)
Available Online at

http://sttberea.ac.id/e-journal/index.php/logia

DOI : $10.37731 / \log . v 1 i 1.21$

masyarakat Yerusalem pada waktu itu karena Yesus bukan sekedar mengajar tetapi melakukan berbagai mujizat. Seorang Rabbi datang dan memilih murid-Nya. Tetapi uniknya Yesus sebagai seorang Rabbi Yahudi justru memilih orang-orang biasa yang tidak terkenal dan memiliki reputasi 'orang-orang marginal' di kalangan mereka. Konteks sosial masyarakat Yahudi pada waktu itu memang terbagi-bagi dalam berbagai strata sehingga pilihan Yesus sangat mencengangkan. Namun demikian Yesus sangat mengasihi mereka dan menjadikan mereka para penjala manusia bahkan menjadi penerus ajaran-Nya sampai ke ujung bumi mengenal nama-Nya.

Di samping itu ada pula yang memutuskan untuk mengikut Yesus dengan menyebut Yesus guru. Di dalam Matius 8:19, ahli Taurat pun rindu mengikut Yesus. Ex mero motu dalam Bahasa Latin berarti hasrat yang timbul dari kehendak hatinya sendiri. la tidak dipanggil oleh Kristus menjadi murid-Nya tetapi atas kemauannya sendiri, ia memberi diri untuk menjadi pengikut Kristus yang dekat dengan sukarela. Persoalannya Yesus sebagai seorang Rabbi, memiliki standar tinggi yang tidak mudah dijalani oleh murid-murid-Nya. Banyak orang berkata ingin melayani, ingin menjadi murid Kristus tetapi akhirnya mengalami kekecewaan karena ternyata apa yang dibayangkan tidak sama dengan kenyataan. Mengikut Yesus harus siap berkorban, dilecehkan, membatasi diri dengan berbagai keinginan daging, dan harus terus berbagi kasih tanpa terkecuali. Ini standar yang berbeda dengan guru-guru lain pada umumnya. Itu sebabnya Yesus layak disebut Rabbi atau seorang guru besar yang bisa mentransformasi hidup manusia.

Anak Manusia (9:6; 16:27; 17:12, 22; 20:28; 24:27; 26:2,24,45;26:64)

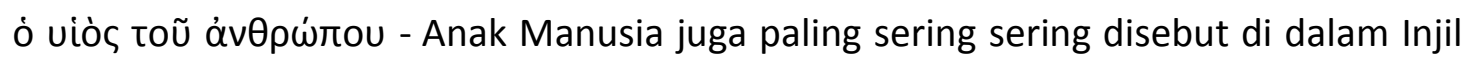
Matius. Di dalam konteks orang Yahudi, mereka memahami bahwa sang Mesias adalah seorang anak manusia biasa yang diurapi oleh Allah. Ketika Yesus menyembuhkan orang lumpuh, Yesus berkata bahwa Anak Manusia berkuasa mengampuni dosa manusia, bukan sekedar menyembuhkan penyakit (9:6). Ini adalah kekhususan dari pengakuan tersebut karena dapat dilihat bahwa di dunia ini banyak orang juga bisa membuat hal-hal menakjubkan seperti menyembuhkan sakit tetapi hanya Yesus yang punya kuasa untuk mengampuni dosa manusia. Tidak ada pribadi lain yang pernah berkata seperti itu. Tidak ada nabi lain yang berani menyatakan-Nya. Yesus menjelaskan bahwa kuasa itu ada pada-Nya. Yesus juga mengatakan apa yang akan terjadi dengan diri-Nya bahwa Anak Manusia akan 
LOGIA : Jurnal Teologi Pentakosta

Vol. 1, No. 1 (Desember 2019)

ISSN : 2716-4322 (Cetak) 2716-2834 (Online)
Available Online at http://sttberea.ac.id/e-journal/index.php/logia DOI : $10.37731 / \log . v 1 i 1.21$

datang dalam kemuliaan diiringi para malaikat-Nya, dan berhak menghakimi manusia menurut perbuatannya (16:27). Yesus juga berkata tentang penderitaan yang harus ditanggung oleh Anak Manusia ini (17:12), diserahkan ke dalam tangan manusia (17:22). Yesus menempatkan diri-Nya sebagai pribadi yang akan mengalami hal-hal tersebut. Sekalipun murid-murid-Nya tidak memahami apa yang Yesus katakan, la tetap berkali-kali mengatakan bahwa semua itu memang harus terjadi karena sudah ditentukan oleh Allah bahwa kedatangan-Nya untuk melayani dan bukan untuk dilayani, bahkan menjadi tebusan atas dosa manusia (20:28). Yesus bukan hanya menyatakan apa yang akan dialami oleh Anak Manusia pada masa itu, namun masih ada pengharapan bahwa di jaman akhir, Anak Manusia akan kembali datang dengan kondisi dan otoritas yang berbeda. la akan menjadi raja kekal untuk seluruh dunia.

Penekanan istilah ini adalah “Anak Manusia” yang ditetapkan Allah, melalui kelahiran dari seorang perempuan yang bernama Maria dan dengan demikian menjadi manusia yang sempurna. Allah memakai cara tersebut untuk menjadikan manusia mampu mengenal Allah dalam kehidupan nyata melalui Anak Manusia tersebut. Allah yang menjadi manusia terlahir dalam dunia yang rusak dan kehilangan hakekat aslinya bahwa manusia diciptakan baik adanya. Akibat dosa manusia kehilangan gambar dirinya sehingga Allah yang menjadi manusia mampu menunjukkan bahwa manusia yang memiliki gambar/citra Allah hidup di dalam dunia tetapi memiliki standar yang berbeda dari manusia dunia pada umumnya.

Yesus sendiri sering mengungkapkan identitas diri-Nya dengan sebutan Anak Manusia sehingga sering muncul berbagai penafsiran tentang istilah tersebut. Pengertian yang dapat dipertimbangkan diantaranya adalah:

a. Memperlihatkan pandangan Yesus sendiri tentang identitasnya.

b. Merupakan gelar yang diberikan masyrakat Kristen.

c. Sebutan yang mengarah kepada eskatologi.

d. Sebutan kepada Anak Manusia surgawi yang sedang dinyatakan pada saat ini.

e. Mengarah kepada kehidupan Yesus selama berada di dunia. 7

\section{Hamba Tuhan (12:18)}

Yesus sebagai Hamba Tuhan yang diurapi, sudah dinubuatkan dalam kitab Yesaya 42:1-4.Istilah dalam bahasa Ibrani yaitu sebagai seorang ebed $Y H W H$, melakukan pekerjaan-

\footnotetext{
${ }^{7}$ Donald Guthrie, Teologi Perjanjian Baru 1 (Jakarta: BPK Gunung Mulia, 2008). 305.
} 
LOGIA : Jurnal Teologi Pentakosta

Vol. 1, No. 1 (Desember 2019)

ISSN : 2716-4322 (Cetak) 2716-2834 (Online)
Available Online at

http://sttberea.ac.id/e-journal/index.php/logia

DOI : $10.37731 / \log . v 1 \mathrm{il} .21$

Nya dengan ketaatan mutlak dan la mendapatkan perkenanan mutlak dari Tuhan. Hamba

Tuhan ini secara khusus berbicara tentang identitas Yesus yang sedang on mission menjalankan tugas atau perintah dari Tuhan. Itu sebabnya dalam pelaksanaan tugas kenabian tersebut, Yesus selalu mengajarkan hal-hal yang dikehendaki oleh Allah Bapa, melakukan mujizat untuk memuliakan Allah Bapa, menunjukkan wibawa dalam setiap tindakan dan perkataan sebagaimana selayaknya mereka menghormati Allah Bapa.

Yesus sebagai hamba ketika Dia harus menanggung dosa umat manusia. Ketika Yesus memulai pekerjaan-Nya, terdengar suara dari langit: "Inilah Anak yang Kukasihi, kepadaNyalah Aku berkenan" (Mat. 3:17). Pernyataan itu terulang kembali Lihatlah, itu Hamba-Ku yang Kupilih, yang Kukasihi, yang kepada-Nya jiwa-Ku berkenan; Aku akan menaruh roh-Ku ke atas-Nya, dan la akan memaklumkan hukum kepada bangsa-bangsa. (Mat 12:18). Kalimat itu diambil dari Yesaya 42:1 mengenai hamba Tuhan yang menderita. Jadi Yesus menjadi hamba Tuhan yang 'menanggung dosa banyak orang". la tidak dibaptiskan karena la berbuat dosa tetapi oleh sebab la menyamakan diri dengan umat manusia. Tugas-Nya adalah memulihkan kembali hubungan yang rusak antara Allah dengan manusia karena dosa. ${ }^{8}$

\section{Penyaliban}

\section{Raja orang Yahudi (27:37)}

Peristiwa penyaliban yang merupakan hukuman terkutuk bagi kriminal paling jahat merupakan peristiwa memalukan dan menakutkan bagi orang pada umumnya. Namun bagi orang yang percaya Yesus justru menjadi lambing kemenangan Kristus atas dosa manusia. Kata-kata Yesus di atas kayu salib ta telestai mengakhiri segenap tugasnya dengan sempurna. Demikian juga dengan istilah raja orang Yahudi pada awalnya dijadikan bahan olok-olok malah berubah menjadi pembuktian bahwa semua yang dikatakan oleh para nabi di masa Perjanjian Lama telah tergenapi. Pengakuan bahwa Yesus sebagai seorang Raja bagi mereka yang sudah ditebus dengan darah-Nya. Yesus tidak melanggar satu titik perintah yang harus dijalani-Nya. Dia taat dan setia sampai titik darah penghabisan. Allah tidak memberikan keringanan atas hukuman dosa. Dia menunjukkan keadilan-Nya dengan menetapkan hokum yang sama bahwa keseriusan dosa memang harus dibebaskan dengan darah yang tidak bercacat dan bernoda. Yesus menjalani semuanya itu dengan keikhlasan

\footnotetext{
${ }^{8}$ B.J. Boland, Intisari Iman Kristen (Jakarta: BPK Gunung Mulia, 2006).39.
} 
LOGIA : Jurnal Teologi Pentakosta

Vol. 1, No. 1 (Desember 2019)

ISSN : 2716-4322 (Cetak) 2716-2834 (Online)
Available Online at http://sttberea.ac.id/e-journal/index.php/logia DOI : $10.37731 / \log . v 1 \mathrm{il} .21$ hati dan rela meninggalkan semua kuasa dan otoritas-Nya demi sebuah pengampunan dosa. Itu sebabnya Yesus layak disebut sebagai raja orang Yahudi.

\section{Anak Allah (27:54)}

$\dot{\alpha} \lambda \eta \theta \tilde{\omega}$ ৎ $\theta \varepsilon$ cõ viòs ñरv oũtos (adelphos theou uios en outos) Seruan yang keluar dengan tulus dan murni. Kali ini pengakuan identitas Yesus keluar dari mulut seorang kepala pasukan prajurit yang menyaksikan semua yang terjadi dalam peristiwa penyaliban Yesus. Dia mengakui Yesus sebagai Anak Allah dan tidak memasalahkan hal-hal yang bersifat logika istilah 'anak'. Pengakuan itu membuktikan bahwa Roh Kudus bekerja di dalam diri orangorang yang melihat dan menjadi saksi kejadian penyaliban itu.

Kenyataan bahwa Yesus adalah Anak Allah menunjukkan keberadaan divine sonship atau keputra ilahian Yesus. Seruan ini menunjukkan kesungguhan yang tidak dipaksakan, mengingat konteks peristiwa penyaliban yang jelas tidak ada paksaan untuk mengaku percaya. Tetapi semua kejadian dalam drama penyaliban itu telah mengubah pola pikir seorang perwira yang sebelumnya justru ikut melukai Yesus. Ini adalah ungkapan kebesaran yang disandangkan kepada Yesus karena Dia bukan sekedar manusia biasa. Karena di dalam penyaliban-Nya, Yesus bisa menanggung semuanya tanpa sedikitpun mengeluh bahkan sikap kepasrahan kepada Allah Bapa telah ditunjukkan kepada semua saksi mata bahwa mereka telah melakukan sebuah kesalahan besar dengan menyalibkan Yesus. Namun justru melalui itu, karya penebusan Yesus bisa diselesaikan dengan tuntas. ${ }^{9}$

\section{IMPLEMENTASI DALAM BERAPOLOGETIKA}

\section{Dasar Apologetika}

Apologetika adalah bagian dari bidang ilmu teologi yang bertujuan untuk melakukan pembelaan iman sendiri. Apologetics (from Greek áro入oyia, "speaking in defense") is the religious discipline of defending religious doctrines through systematic argumentation and discourse. ${ }^{10}$

Pertanyaan yang sering dimunculkan berkaitan dengan iman Kristen adalah : benarkah Yesus Anak Allah? Mengapa Yesus disamakan dengan Allah? Dan banyak lagi persoalan lain. Artikel ini tidak akan menjawab secara langsung pertanyaan tersebut

\footnotetext{
${ }^{9}$ Robert Boehlke, Siapakah Yesus Sebenarnya? (Jakarta: BPK Gunung Mulia, 1985).12.

${ }^{10}$ https://en.wikipedia.org/wiki/Apologetics, diakses pada tanggal 25 Agustus 2019, pada pukul 08.51 WIB.
} 
LOGIA : Jurnal Teologi Pentakosta

Vol. 1, No. 1 (Desember 2019)

ISSN : 2716-4322 (Cetak) 2716-2834 (Online)
Available Online at

http://sttberea.ac.id/e-journal/index.php/logia

DOI : $10.37731 / \log . v 1 \mathrm{i} 1.21$

(sebagian sudah dipaparkan di atas). Artikel ini ingin memberikan saran sikap atau cara berapologet yang baik. Sesuai dengan definisinya, berapologet sebenarnya adalah sedang membela iman atau mempertanggungjawabkan apa yang dipercayai atau diyakini oleh seseorang. Ketika pembicaraan mengarah kepada sebuah perdebatan, maka apologet tersebut tidak akan tercapai dengan baik karena tujuannya bukan siapa benar siapa salah. Apologetika lebih bersifat pertanggungjawaban iman. Sehingga ketika seseorang ditanya tentang Yesus Sang Mesias, Anak Allah yang hidup, la dapat menjelaskan dengan baik karena memiliki pengenalan secara pribadi yang perlu terus dikembangkan. Sebagaimana Horton menyatakan:

"Iman bukanlah sebuah lompatan subyektif. Iman adalah kepercayaan yang masuk akal kepada Allah yang menyatakan diri-Nya dengan jelas di dalam Injil. Seluruh iman Kristen tidak disandarkan pada perasaan, pengalaman dan sentiment moral kolektif kita, tetapi pada pemberitaan terbuka bahwa Allah sudah bertindak dalam sejarah untuk menyelamatkan kita dari dosa dan maut"11.

Berapologetika bukan didasarkan kepada akal atau dogmatika saja, tetapi pengenalan terhadap Tuhan yang hidup. Dogmatika memberikan rambu-rambu atau pedoman iman, tetapi tetap harus mampu memberikan implikasi dari Firman Tuhan dengan pendekatan kontekstual dan merefleksikannya dalam hidup sehari-hari. Tujuan dari apologetika adalah untuk memberikan pertanggungjawaban, jadi kita sendiri harus bertanggungjawab atas iman kita bukan orang lain yang mengajarkan dengan teori-teori menjawab pertanyaan yang kadangkala bertujuan menjebak atau menjatuhkan. Jika tujuannya mencari kebenaran atau menggali bersama, maka ketrampilan kita untuk menggali lebih dalam teks-teks Alkitab akan sangat menolong untuk berapologet dan mempertahankan iman.

\section{Implementasi dalam berapologetika}

Beberapa implikasi dalam berapologetika dari ulasan di atas yang dapat ditemukan adalah:

1. Perspektif Relasional

\footnotetext{
${ }^{11}$ Michael Horton, Core Christianity (Inti Iman Kristen (Michigan: Baker Books, 2002).21.
} 
Yesus sebagai Anak Allah bukan berarti keturunan secara biologis tetapi lebih mengarah ke dalam arti relasional antara Bapa dan Anak. Hubungan yang dekat dan saling mengenal menggambarkan sebuah hubungan ilahi antara Allah yang mendekati manusia, bahkan menyelaminya dalam wujud manusia lemah tetapi berkuasa. Allah tidaktinggal di surge sebagai yang "Maha" tanpa peduli bahwa manusia tidak bisa melepaskan dirinya sendiri dari dosa. Sebaliknya karena Allah sendiri adalah kasih, maka la rela memberikan "Anak-Nya" yang terkasih untuk menjadi korban penebusan sehingga persoalan dosa dapat diselesaikan. Bukan hanya berhenti di situ, keberadaan Yesus sebagai Anak Allah menunjukkan kehormatan yang tinggi, karena pernyataan itu justru diberikan oleh orang lain, Allah sendiri, bahkan malaikat dan iblis mengakuinya.

2. Perspektif Identitas

Pernyataan tentang Yesus sebagai Anak Allah justru dimunculkan dari orang lain : Allah Bapa sendiri, Simon Petrus, dan kepala pasukan prajurit. Pihak-pihak yang mengakui Yesus sebagai Anak Allah adalah orang-orang yang mengenal Yesus dari dekat sehingga mereka dapat mengakui identitas Yesus dengan keakuratan dan bisa dipercaya. Jika hubungan kita dengan seseorang tidak dekat, maka sebutan atau pernyataan kita tidak dapat dipertanggungjawabkan. Namun dari kisah dalam Injil Matius, semua pengakuan tersebut keluar dari mulut atau hati yang tulus setelah mereka mengalami peristiwaperistiwa yang menyentuh hati mereka. Dengan kata lain identitas Yesus menjadi sangat berbeda setelah ada pengenalan secara pribadi dengan-Nya. Yesus sendiri ketika berbicara tentang identitasnya lebih sering menggunakan istilah Anak Manusia. Hal ini dikarenakan konteks situasi saat itu yang sangat fanatik dengan hal-hal menyangkut keallah-an. Namun dapat pula ditafsirkan bahwa Yesus memilih untuk merendahkan diriNya dan mengijinkan orang lain mengatakan siapa Dia sebenarnya.

3. Perspektif Hamba

Yesus menempatkan diri sebagai hamba Tuhan yang taat dan menjadikan Allah Bapa sebagai bapa bagi semua orang percaya berarti sebagai Bapa rohani atau lebih daripada itu yaitu sebagai Bapa yang layak disembah dan dimuliakan. Di dalam berbagai pernyataan-Nya, Yesus selalu mengatakan kepada murid-murid maupun orang-orang yang mengikuti-Nya untuk menyembah kepada Bapa(mu) saja. Ini menunjukkan status Anak Allah tidak menjadikan Dia pewaris tunggal kekuasaan Bapa, tetapi justru Yesus 
LOGIA : Jurnal Teologi Pentakosta

Vol. 1, No. 1 (Desember 2019)

ISSN : 2716-4322 (Cetak) 2716-2834 (Online)
Available Online at

http://sttberea.ac.id/e-journal/index.php/logia

DOI : $10.37731 / \log . v 1 \mathrm{i} 1.21$

mengajak kita menjadi anak-anak Allah juga sehingga bisa menyebut Allah itu sebagai Bapa kita semua juga. Ketundukan hamba yang diangkat menjadi anak tentunya menjadikan perubahan besar dalam hidup seseorang. Sejak percaya kepada Yesus, maka hidupnya bukan lagi hamba kepada dosa, kepada dunia, melainkan menjadi anak-anak Allah yang hidup taat melakukan kehendak Allah Bapa.

4. Perspektif Rohani

Yesus sebagai Anak Allah dipahami dengan pertolongan Roh Kudus dan bukan sekedar rasio manusia semata. Jika rasio manusia dijadikan dasar pijakan untuk memahami istilah ini maka yang terjadi adalah penyangkalan tentang Allah yang Maha Kuasa dan Maha Suci. Anak Allah bukan berarti denotative tetapi ada makna di balik istilah itu yang harus dipahami dengan benar. Sebagai contoh jika ada frasa 'di balik tangan' maka artinya bukan sekedar ada tangan yang dibalik, tetapi makna yang lebih dalam adalah kegiatan yang sembunyi-sembunyi dan tidak terus terang. Demikian pula ungkapan Anak Allah sebagaimana telah dijelaskan di atas memiliki makna mendalam yang hanya bisa diselami ketika seseorang menggunakan iman percayanya untuk mengendalikan rasionya. Di dalam hal ini Roh Kudus berperan untuk memberi penjelasan yang sulit dan rumit mengenai ANak Allah. Allah yang adalah Roh dapat menjelaskan kepada roh kita agar lebih sungguh-sungguh menjalani hidup dengan kualitas rohani yang baik sehingga Anak Allah tersebut dapat 'hidup' terpancar keluar melalui hidup kita.

\section{KESIMPULAN}

Yesus sebagai Anak Allah sesuai dengan konteks di dalam Injil Matius, telah mengungkapkan bahwa bukan karena kepentingan Yesus untuk mengaku diri-Nya Anak Allah, tetapi justru pengakuan itu dinyatakan sendiri oleh Allah Bapa, oleh malaikat, bahkan iblis, Simon Petrus dan kepala pasukan. Semua pernyataan itu membuktikan bahwa Yesus sebagai Anak Allah bukan menjadi suatu konsep yang dipaksakan atau disuntikkan kepada kita. Namun ketika pengakuan itu muncul, justru dari dalam diri seseorang timbul pengertian atau pengenalan siapa sesungguhnya Yesus sebagai Anak Allah. Dengan demikian perdebatan atau pertentangan isu mengenai benar dan tidaknya Yesus sebagai Anak Allah, tidak dapat didekati hanya dengan rasio semata, namun lebih dalam lagi melalui 
LOGIA : Jurnal Teologi Pentakosta Vol. 1, No. 1 (Desember 2019)

ISSN : 2716-4322 (Cetak) 2716-2834 (Online)
Available Online at http://sttberea.ac.id/e-journal/index.php/logia DOI : $10.37731 / \log . v 1 \mathrm{i} 1.21$

pertolongan Roh Kudus yang memberikan kepada manusia hikmat untuk memahami kebenaran itu.

Dasar apologetika yang digunakan adalah pengenalan kita melalui Firman Tuhan dan memahaminya di dalam konteks Alkitab dan merefleksikannya dalam kehidupan sehari-hari. Sikap hati yang terbuka dan sungguh-sungguh haus akan kebenaran itulah yang dapat menolong kita mengungkapkan kebenaran sejati itu tanpa rasa takut melainkan dengan penuh keyakinan. 
LOGIA : Jurnal Teologi Pentakosta

Vol. 1, No. 1 (Desember 2019)

ISSN : 2716-4322 (Cetak) 2716-2834 (Online)
Available Online at http://sttberea.ac.id/e-journal/index.php/logia DOI : $10.37731 / \log . v 1 \mathrm{i} 1.21$

\section{DAFTAR PUSTAKA}

Internet

http://alkitab.sabda.org/verse commentary.php?book=Mat\&chapter=1\&verse=1, diakses tanggal 22 Agustus 2019, pukul .13.09 WIB.

https://www.biblestudytools.com/dictionaries/bakers-evangelical-

dictionary/immanuel.html, diakses tanggal 22 Agustus 2019, pukul 15.29 WIB

http://www.sarapanpagi.org/86-konsep-mesias-dalam-alkitab-dan-menurut-yahudivt3193.html diakses tanggal 22 Agustus 2019, pukul 16.00 WIB

https://en.wikipedia.org/wiki/Apologetics, diakses pada tanggal 25 Agustus 2019, pada pukul 08.51 WIB.

Buku

Boehlke, Robert. Siapakah Yesus Sebenarnya? Jakarta: BPK Gunung Mulia, 1985.

Boland, B.J. Intisari Iman Kristen. Jakarta: BPK Gunung Mulia, 2006.

Ch. Abineno. Pokok-Pokok Penting Dari Iman Kristen. Jakarta: BPK Gunung Mulia, 2008.

Guthrie, Donald. Teologi Perjanjian Baru 1. Jakarta: BPK Gunung Mulia, 2008.

Horton, Michael. Core Christianity (Inti Iman Kristen. Michigan: Baker Books, 2002.

Pr, Eko Priyadi. Yesus Kristus Tuhan Kita. Yogyakarta: Kanisius, 2011.

Wahono, Wismoady. Di Sini Kutemukan: Petunjuk Mempelajari Dan Mengajarkan Alkitab. Jakarta: BPK Gunung Mulia, 2009. 